\title{
PATTERN RECOGNITION: EFFECTIVENESS OF TEACHING GIRLS AGED 15 ACROBATIC EXERCISES
}

\author{
Davyd Medko ${ }^{1 \mathrm{ABCD}}$, Oleg Khudolii ${ }^{1 \mathrm{ABCD}}$ \\ ${ }^{1}$ H. S. Skovoroda Kharkiv National Pedagogical University \\ Authors' Contribution: A - Study design; B - Data collection; C - Statistical analysis; D - Manuscript Preparation; E - Funds Collection
}

DOI: $10.17309 / \mathrm{jltm} .2021 .3 .05$

\begin{abstract}
The purpose of the study was to determine the impact of exercise modes on the effectiveness of teaching girls aged 15 a cartwheel.

Materials and methods. The study participants were 20 girls aged 15 . The children and their parents were fully informed about all the features of the study and gave their consent to participate in the experiment. To solve the tasks set, the following research methods were used: study and analysis of scientific and methodological literature; pedagogical observation, timing of training tasks; pedagogical experiment, methods of mathematical statistics, discriminant analysis.

Results. The analysis of averages shows that statistically significant differences in the number of repetitions are observed in performing series of training tasks 1,2 , and $4(\mathrm{p}<0.05)$. The girls aged 15 who use the first mode $(6$ sets 1 time each with a rest interval of $60 \mathrm{~s}$ ) need fewer repetitions to master the movements of the first (exercises to develop motor abilities) and the second (exercises to master starting and ending positions) series of tasks. The girls who use the second mode ( 6 sets 2 times each with a rest interval of $60 \mathrm{~s}$ ) need fewer repetitions to master the movements of the fourth series of tasks (ability to assess movements in space, by time and muscular effort) $(\mathrm{p}<0.05)$.

Conclusions. Discriminant analysis made it possible to determine the impact of the number of repetitions on the effectiveness of developing the cartwheel skill in girls aged 15.

During motor skills development, both the first and the second variants of exercise modes and rest intervals can be used. For series of tasks 1 and 2, it is advisable to use 6 sets 1 time each with a rest interval of $60 \mathrm{~s}$; for series of tasks 3 , 5 , and $6-6$ sets 1 time each with a rest interval of 60 s or 6 sets 2 times each with a rest interval of 60 s; for series $4-6$ sets 2 times each with a rest interval of $60 \mathrm{~s}$.
\end{abstract}

Keywords: discriminant analysis, girls aged 15, acrobatic exercises, exercise mode, teaching.

\section{Introduction}

One of the priorities of the modern school is motor skills development (Ivashchenko, 2020; Ivashchenko, Berezhna, \& Cieślicka, 2020; Ivashchenko, \& Sirichenko, 2020). The level of proficiency in exercises determines the variation of testing results by $29.772 \%$, and motor skills development is a priority in the educational process at school (Ivashchenko, Berezhna, \& Cieślicka, 2020; Ivashchenko, \& Sirichenko, 2020).

Fundamental motor skills are considered as the basis of physical education of schoolchildren (Chan, Ha, \& Ng, 2018; Chan, Ha, Ng, \& Lubans, 2019; Valentini, Pierosan, Rudisill, \& Hastie, 2017). Fundamental motor skills (FMS) are divided into object control skills (for example, catching and throwing), locomotor skills (for example, running and jumping), and stability skills (for example, balancing) (Almeida, Luz, Martins, \& Cordovil, 2017; Basman, 2019; Barnett, Telford,

(c) Medko, D., \& Khudolii, O., 2021.
Strugnell, Rudd, Olive, \& Telford, 2019). Chan et al. (2018, 2019) point out that the level of motor competence is the basis of physical activity and sports engagement of schoolchildren. Valentini, Pierosan, Rudisill, \& Hastie (2017) argue that the process of developing motor skills should be a priority of motor activity. Nobre, Valentini, \& Rusidill (2020) note that motor skills development in schoolchildren depends on educational policies and training of physical education teachers.

The effectiveness of teaching depends on the level of schoolchildren's motor fitness (Ivashchenko, Iermakov, Khudolii, Cretu, \& Potop, 2017; Marchenko, \& Dykhanova, 2019), selection of physical exercises (Ivashchenko, \& Kapkan, 2015; Khudolii, Ivashchenko, \& Chernenko, 2015; Ivashchenko, Khudolii, Iermakov, \& Harkusha, 2017), and modes of alternating physical exercises and rest intervals (Khudolii, Ivashchenko, \& Beketov, 2015; Marchenko, \& Taranenko, 2020). Therefore, it is relevant to study the impact of exercise modes on motor skills development. 
The purpose of the study was to determine the peculiarities of impact of exercise modes on the effectiveness of teaching girls aged 15 a cartwheel.

\section{Material and methods}

\section{Study participants}

The study participants were 20 girls aged 15 . The children and their parents were fully informed about all the features of the study and gave their consent to participate in the experiment.

\section{Organization of the study}

To solve the tasks set, the following research methods were used: study and analysis of scientific and methodological literature; pedagogical observation, timing of training tasks; pedagogical experiment, methods of mathematical statistics, methods of mathematical experiment planning, discriminant analysis.

The pedagogical experiment examined the influence of 6 and 12 repetitions with a 60-second rest interval during a physical education class on the number of repetitions of training tasks to the $100 \%$ level of proficiency. In the first group $(n=10)$, the girls repeated the tasks 6 sets 1 time each with a rest interval of $60 \mathrm{~s}$, in the second group $(n=10)-6$ sets 2 times each with a rest interval of $60 \mathrm{~s}$.

During teaching, the method of algorithmic instructions was used (Shlemin, 1973). The program of teaching the cartwheel was developed based on the data of Shlemin (1973), Khudolii (2008) and included the following training tasks:

The first series of training tasks - exercises to develop motor abilities

1. From normal standing position, lean forward, touch the floor with the hands and, moving the hands forward on the floor, adopt a push-up position, return to starting position in the same way 3-4s)

2. Perform push-ups as quickly as possible (5 times in

The second series of training tasks - exercises to master starting and ending positions

1. From standing position with raised arms, step forward and perform a switch leg handstand with assistance

2. Handstand with legs apart with assistance

The third series of training tasks - actions without which it is impossible to perform the target exercise
1. Standing on hands with legs apart with assistance, shift the body weight from one hand to the other

The fourth series of training tasks - teaching the ability to assess movements in space, by time and muscular effort

1. Arriving to handstand quickly with assistance

2. Arriving to handstand slowly with assistance

The fifth series of training tasks - preliminary exercises

1. Arriving to handstand quickly with the wall support

2. Handstand with legs apart with 90-degree rotation with assistance

The sixth series of training tasks - the entire exercise

1. Cartwheel with assistance.

2. Cartwheel without assistance

The next exercise started on condition of correct performance of the previous exercise on three consecutive attempts. The number of repetitions required for correct performance on three consecutive attempts was recorded. The level of proficiency in the exercises was determined by the alternative method: "performed" or "failed". A technically correct performance of the exercise gave the students " 1 " point; a failure to perform the exercise gave them " 0 " entered in the protocol.

\section{Statistical analysis}

The study materials were processed using the IBM SPSS 20 statistical analysis program. Discriminant analysis was conducted. For each canonical discriminant function, the study calculated the following: eigenvalue, variance percentage, canonical correlation, Wilks' lambda, Chi-square. For each step: prior probabilities, Fisher's function coefficients, unstandardized function coefficients, Wilks' lambda for each canonical function.

The study protocol was approved by the Ethical Committee of the University. In addition, the children and their parents or legal guardians were fully informed about all the features of the study, and a signed informed consent document was obtained from all the parents.

\section{Results}

The analysis of averages shows that statistically significant differences in the number of repetitions are observed in performing series of training tasks 1,2 , and 4 ( $p<0.05)$. The girls aged 15 who use the first mode ( 6 sets 1 time each with a rest interval of $60 \mathrm{~s}$ ) need fewer repetitions to master the movements of the first (exercises to develop motor abilities) and the second (exercises to master starting and ending posi-

Table 1. Group Statistics. Girls Aged 15

\begin{tabular}{|c|c|c|c|c|c|c|c|c|c|c|}
\hline \multirow{2}{*}{ Series of tasks } & \multicolumn{2}{|c|}{$\begin{array}{c}6 \text { repetitions, rest interval } \\
\text { of } 60 \mathrm{~s}\end{array}$} & \multicolumn{2}{|c|}{$\begin{array}{c}12 \text { repetitions, rest interval } \\
\text { of } 60 \mathrm{~s}\end{array}$} & \multirow{2}{*}{$\Delta \mathbf{x}$} & \multirow{2}{*}{$\begin{array}{l}\text { Wilks' } \\
\text { Lambda }\end{array}$} & \multirow{2}{*}{$\mathbf{F}$} & \multirow{2}{*}{ df1 } & \multirow{2}{*}{ df2 } & \multirow{2}{*}{ Sig. } \\
\hline & Mean & Std. Deviation & Mean & Std. Deviation & & & & & & \\
\hline 1 & 7.5 & 0.84 & 8.8 & 0.91 & -1.3 & 0.625 & 10.787 & 1 & 18 & 0.004 \\
\hline 2 & 6.8 & 0.78 & 8.4 & 0.84 & -1.6 & 0.484 & 19.200 & 1 & 18 & 0.000 \\
\hline 3 & 11.4 & 0.84 & 10.6 & 0.96 & 0.8 & 0.822 & 3.892 & 1 & 18 & 0.064 \\
\hline 4 & 9.9 & 1.19 & 7.8 & 1.03 & 2.1 & 0.505 & 17.640 & 1 & 18 & 0.001 \\
\hline 5 & 9.0 & 1.33 & 9.2 & 1.31 & -0.2 & 0.994 & 0.114 & 1 & 18 & 0.740 \\
\hline 6 & 7.5 & 0.84 & 7.8 & 1.03 & -0.3 & 0.973 & 0.503 & 1 & 18 & 0.487 \\
\hline
\end{tabular}


tions) series of tasks. The girls who use the second mode (6 sets 2 times each with a rest interval of $60 \mathrm{~s}$ ) need fewer repetitions to master the movements of the fourth series of tasks (ability to assess movements in space, by time and muscular effort) $(\mathrm{p}<0.05)$ (Table 1$)$.

To determine the impact of different modes of exercises on the level of proficiency, discriminant analysis was conducted (Tables 2-6). A necessary condition for discriminant analysis is the homogeneity of variances and covariances of data. The Box's $M$ test confirms the assumption about the homogeneity of variances and covariances ( $F=35.896$; $\mathrm{p}=0.368)$ (Table 2).

Table 2. Box's M Test For Testing Equal Population Covariance Matrices (DA)

\begin{tabular}{clc}
\hline & Box's $\mathbf{M}$ & $\mathbf{3 5 . 8 9 6}$ \\
\hline \multirow{4}{*}{ F } & Approx. & 1.076 \\
& df1 & 21 \\
& df2 & 1191.671 \\
& Sig. & 0.368 \\
\hline
\end{tabular}

The first canonical function explains $100 \%$ of the results variation, which indicates its high informativity $(r=0.949)$ (see Table 3). The analysis of the canonical function shows its statistical significance $(\lambda 1=0.099 ; \mathrm{p} 1=0.001)$. The first function has a high discriminative ability and value in interpretation of the general population (Table 4).

Table 3. Eigenvalues for Developing Discriminant Model (Canonical Correlation). Girls Aged 15

\begin{tabular}{|c|c|c|c|c|}
\hline Function & Eigenvalue & $\begin{array}{c}\% \\
\text { of Variance }\end{array}$ & $\begin{array}{c}\text { Cumulative } \\
\%\end{array}$ & $\begin{array}{c}\text { Canonical } \\
\text { Correlation }\end{array}$ \\
\hline 1 & 9.056 & 100.0 & 100.0 & .949 \\
\hline
\end{tabular}

Table 4. Outcomes of Calculated Wilks' Lambda of Discriminant Function. Girls Aged 15

\begin{tabular}{ccccc}
\hline Test of Function(s) & Wilks' Lambda & Chi-square & df & Sig. \\
\hline 1 & 0.099 & 34.623 & 6 & 0.000 \\
\hline
\end{tabular}

The standardized canonical discriminant function coefficients make it possible to determine the ratio of the contribution of variables to the function result. The results of the sixth, second, fourth, and first series of training tasks make the largest contribution to the first canonical function. The above indicates that in the classification of exercise modes for girls aged 15, the results of all series of training tasks are significant (Table 5).

Table 5. Standardized Canonical Discriminant Function Coefficients. Girls Aged 15

\begin{tabular}{cc}
\hline Series of tasks & Function \\
\cline { 2 - 2 } & Series 1 \\
Series 2 & 0.854 \\
Series 3 & 0.903 \\
Series 4 & -0.879 \\
Series 5 & -0.888 \\
Series 6 & -0.426 \\
\hline
\end{tabular}

The structure canonical discriminant function coefficients are the coefficients of correlation between the variables and the function. Thus, the function is most closely connected with the number of repetitions of exercises of the second and fourth series of training tasks $\left(r_{2}=0.343 ; r_{4}=-0.329\right)$ (Table 6).

Table 6. Structure Matrix. Girls Aged 15

\begin{tabular}{cc}
\hline Series of tasks & Function \\
\cline { 2 - 2 } & Series 2 \\
Series 4 & 0.343 \\
Series 1 & -0.329 \\
Series 3 & 0.257 \\
Series 6 & -0.155 \\
Series 5 & 0.056 \\
\hline
\end{tabular}

Table 7. Canonical Discriminant Function Coefficients (Unstandardized coefficients)

\begin{tabular}{cc}
\hline Series of tasks & Function \\
\cline { 2 - 2 } & $\mathbf{1}$ \\
\hline Series 1 & 0.965 \\
Series 2 & 1.107 \\
Series 3 & -0.969 \\
Series 4 & -0.794 \\
Series 5 & -0.322 \\
Series 6 & 1.021 \\
(Constant) & -3.473 \\
\hline
\end{tabular}

Table 8. Functions at Group Centroids. Girls Aged 15

\begin{tabular}{lc}
\hline \multicolumn{1}{c}{ Exercise Mode } & Function \\
\cline { 2 - 2 } & \multicolumn{1}{c}{$\mathbf{1}$} \\
\hline $1-6$ repetitions, rest interval of $60 \mathrm{~s}$ & -2.855 \\
$2-12$ repetitions, rest interval of $60 \mathrm{~s}$ & 2.855 \\
\hline
\end{tabular}

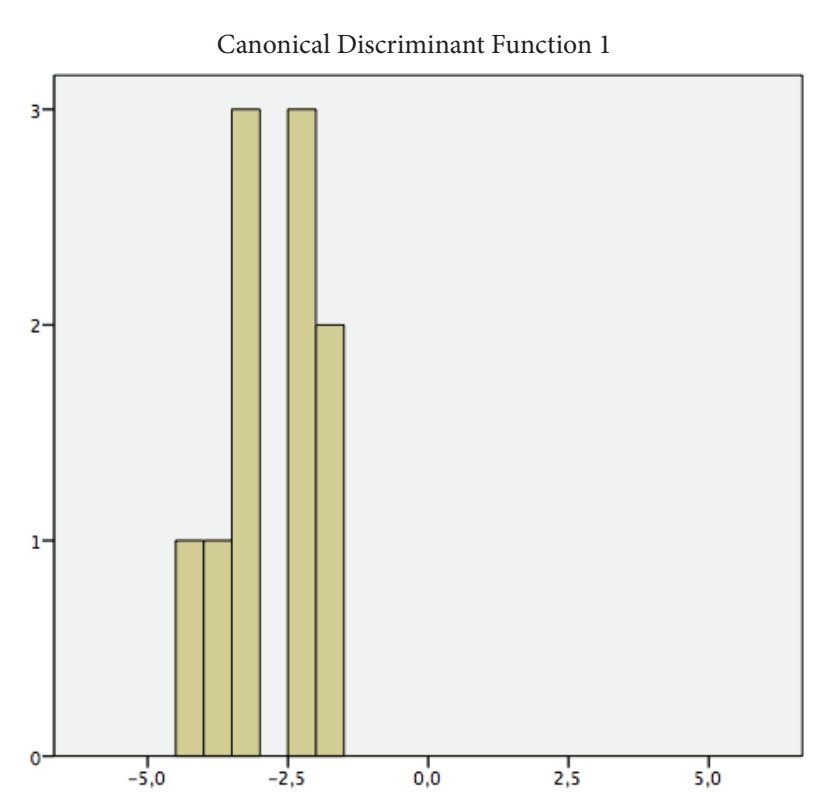

Fig. 1. Graphic representation of classification results: 6 repetitions, rest interval of $60 \mathrm{~s}$ 
Table 9. Classification Results ${ }^{\mathrm{a}, \mathrm{c}}$

\begin{tabular}{|c|c|c|c|c|c|}
\hline & & \multirow[t]{2}{*}{ Exercise Mode } & \multicolumn{2}{|c|}{$\begin{array}{c}\text { Predicted Group } \\
\text { Membership }\end{array}$} & \multirow[t]{2}{*}{ Total } \\
\hline & & & 1 & 2 & \\
\hline \multirow{4}{*}{ Original } & \multirow{2}{*}{ Count } & $1-6$ repetitions, rest interval of $60 \mathrm{~s}$ & 10 & 0 & 10 \\
\hline & & $2-12$ repetitions, rest interval of $60 \mathrm{~s}$ & 0 & 10 & 10 \\
\hline & \multirow{2}{*}{$\%$} & $1-6$ repetitions, rest interval of $60 \mathrm{~s}$ & 100.0 & .0 & 100.0 \\
\hline & & $2-12$ repetitions, rest interval of $60 \mathrm{~s}$ & .0 & 100.0 & 100.0 \\
\hline \multirow{4}{*}{ Cross-validated $^{\mathrm{b}}$} & \multirow{2}{*}{ Count } & $1-6$ repetitions, rest interval of $60 \mathrm{~s}$ & 10 & 0 & 10 \\
\hline & & $2-12$ repetitions, rest interval of $60 \mathrm{~s}$ & 1 & 9 & 10 \\
\hline & \multirow{2}{*}{$\%$} & $1-6$ repetitions, rest interval of $60 \mathrm{~s}$ & 100.0 & .0 & 100.0 \\
\hline & & $2-12$ repetitions, rest interval of $60 \mathrm{~s}$ & 10.0 & 90.0 & 100.0 \\
\hline
\end{tabular}

a. $100.0 \%$ of original grouped cases correctly classified.

b. Cross validation is done only for those cases in the analysis. In cross validation, each case is classified by the functions derived from all cases other than that case.

c. $95.0 \%$ of cross-validated grouped cases correctly classified.

Canonical Discriminant Function 1

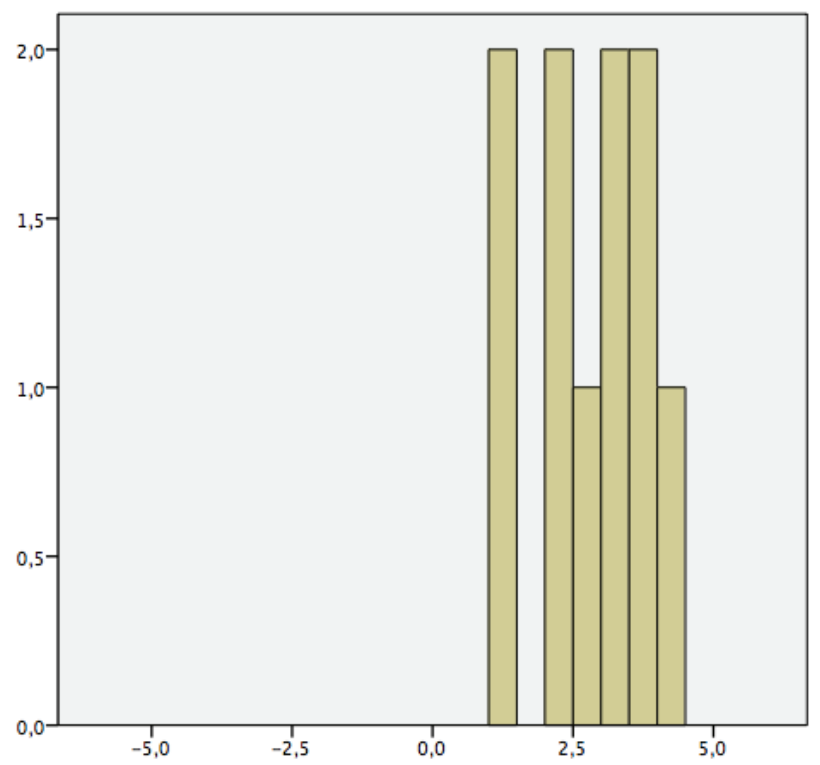

Fig. 2. Graphic representation of classification results: 12 repetitions, rest interval of $60 \mathrm{~s}$

The coordinates of centroids for two groups make it possible to interpret the canonical function in relation to the role in classification. At the positive pole is a centroid for the exercise mode of 12 repetitions $\left(M_{12}=2.855\right)$, at the negative $-\mathrm{a}$ centroid for the exercise mode of 6 repetitions $\left(M_{6}=-2.855\right)$ (see Table 8, Fig. 1, 2). This indicates a significant difference in the impact of exercise repetition modes on the number of repetitions required for motor skills development in girls aged 15 during physical education classes. The results of classification of the groups show that $100.0 \%$ of the original grouped cases were classified correctly (Table 9). Based on the discriminant function coefficients and centroids, it is possible to calculate the number of repetitions for mastering the motor skill (Table 7).

\section{Discussion}

The assumption was made about a significant influence of the modes of alternating exercise repetitions and the rest interval on the effectiveness of motor skills development in girls aged 15. It was found that statistically significant differences in the number of repetitions are observed in performing series of training tasks 1,2 , and $4(\mathrm{p}<0.05)$. The girls aged 15 who use the first mode ( 6 sets 1 time each with a rest interval of $60 \mathrm{~s}$ ) need fewer repetitions to master the movements of the first (exercises to develop motor abilities) and the second (exercises to master starting and ending positions) series of tasks. The girls who use the second mode ( 6 sets 2 times each with a rest interval of $60 \mathrm{~s}$ ) need fewer repetitions to master the movements of the fourth series of tasks (ability to assess movements in space, by time and muscular effort) $(\mathrm{p}<0.05)$.

The results presented show that during motor skills development, both the first and the second variants of exercise modes and rest intervals can be used. For series of tasks 1 and 2 , it is advisable to use 6 sets 1 time each with a rest interval of $60 \mathrm{~s}$; for series of tasks 3, 5, and $6-6$ sets 1 time each with a rest interval of $60 \mathrm{~s}$ or 6 sets 2 times each with a rest interval of $60 \mathrm{~s}$; for series $4-6$ sets 2 times each with a rest interval of $60 \mathrm{~s}$. The obtained data supplement the information about the influence of exercise modes on the effectiveness of motor skills development (Ivashchenko, \& Kapkan, 2015; Marchenko, \& Taranenko, 2020), and also confirm the results of the study on the priority of motor skills development in physical education of schoolchildren (Ivashchenko, Berezhna, \& Cieślicka, 2020; Ivashchenko, \& Sirichenko, 2020; Valentini, Pierosan, Rudisill, \& Hastie, 2017).

Structure coefficients show that the indicators of the effectiveness of teaching girls aged 15 the cartwheel are training tasks of series 2 (exercises to master starting and ending positions) and 4 (ability to assess movements in space, by time and muscular effort). The obtained data complement the information on the structure of fundamental motor skills, which includes movement coordination skills as a separate component (Almeida, Luz, Martins, \& Cordovil, 2017; Basman, 2019; Barnett, Telford, Strugnell, Rudd, Olive, \& Telford, 2019).

The findings complement the results of discriminant analysis of the process of teaching schoolchildren (Kapkan, Khudolii, \& Bartik, 2019; Lopatiev, Ivashchenko, Khudolii, Pjanylo, Chernenko, \& Yermakova, 2017; Marchenko, Jagiello, Iermakov, Ivashchenko, \& Khudolii, 2021) and testify to its effectiveness.

It is advisable to use these data for planning the process of teaching, and the values of centroids and regression equa- 
tions - for calculating the number of repetitions of motor tasks in a physical education lesson. Table 7 shows the unstandardized coefficients that define the total impact of the number of repetitions on the function value. For calculation, the following equation is used:

$$
\begin{gathered}
\mathrm{Y}=-3.473+0.965 \mathrm{X}_{1}+1.107 \mathrm{X}_{2}-0.969 \mathrm{X}_{3}-0.794 \mathrm{X}_{4}-0.322 \mathrm{X}_{5} \\
+1.021 \mathrm{X}_{6},
\end{gathered}
$$

where $\mathrm{Y}$ is the function value, $\mathrm{X}_{1}-\mathrm{X}_{6}$ are the number of repetitions of series of training tasks. The approximate function value is the value of the centroid for the exercise mode of 6 repetitions $\left(M_{6}=-2.855\right)$.

\section{Conclusions}

Discriminant analysis made it possible to determine the impact of the number of repetitions on the effectiveness of developing the cartwheel skill in girls aged 15 .

Based on the analysis of group centroids, it was found that exercise modes significantly influence the cartwheel skill development in girls aged 15 during physical education classes. The results of classification of the groups show that 100.0 $\%$ of the original grouped cases were classified correctly.

During motor skills development, both the first and the second variants of exercise modes and rest intervals can be used. For series of tasks 1 and 2, it is advisable to use 6 sets 1 time each with a rest interval of $60 \mathrm{~s}$; for series of tasks 3,5 , and $6-6$ sets 1 time each with a rest interval of $60 \mathrm{~s}$ or 6 sets 2 times each with a rest interval of $60 \mathrm{~s}$; for series $4-6$ sets 2 times each with a rest interval of $60 \mathrm{~s}$.

\section{Acknowledgment}

The study was carried out according to the research plan of the Department of Theory and Methodology of Physical Education of H. S. Skovoroda Kharkiv National Pedagogical University within the topic "Theoretical and methodological foundations of modeling the learning process and motor abilities development in children and adolescents" (20132022) (state registration number 0112U002008).

\section{Conflict of interest}

The authors declare that there is no conflict of interest.

\section{References}

Ivashchenko, O., Berezhna, H., \& Cieślicka, M. (2020). Motor Skills in the Structure of Physical Fitness of 7-Year-Old Boys. Journal of Learning Theory and Methodology, 1(1), 14-19. https://doi.org/10.17309/jltm.2020.1.02

Ivashchenko, O., \& Sirichenko, D. (2020). Structure of Motor Fitness of 7-Year-Old Girls. Journal of Learning Theory and Methodology, 1(1), 20-25. https://doi.org/10.17309/jltm.2020.1.03

Ivashchenko, O. V., Iermakov, S. S., Khudolii, O. M., Cretu, M., \& Potop, V. (2017). Level of physical exercises' mastering in structure of 11-13 yrs age boys' motor fitness. Pedagogics, psychology, medical-biological problems of physical training and sports, 21(5), 236-243. https://doi.org/10.15561/18189172.2017.0506

Ivashchenko, O. V., \& Kapkan, O. O. (2015). Simulation of process of 14-15 years old girls' training of light athletic and gymnastic exercises. Pedagogics, psychology, medicalbiological problems of physical training and sports, 19(8), 32-39. https://doi.org/10.15561/18189172.2015.0805

Khudolii, O., Ivashchenko, O., \& Beketov, V. (2015). Technological Approaches to Evaluating Training Effects of Power Load in Primary Schoolers. Teoriâ ta Metodika Fìzičnogo Vihovannâ, (1), 16-25. https://doi.org/10.17309/tmfv.2015.1.1121

Khudolii, O. M., Ivashchenko, O. V., \& Chernenko, S. O. (2015). Simulation of junior shcoolchildren's training to acrobatic exercises and vaults. Pedagogics, psychology, medicalbiological problems of physical training and sports, 19(7), 64-71. https://doi.org/10.15561/18189172.2015.0709.

Ivashchenko, O., Khudolii, O., Iermakov, S., \& Harkusha, S. (2017). Physical exercises' mastering level in classification of motor preparedness of 11-13 years old boys. Journal of Physical Education and Sport, 17(3), 1031-1036. https://doi.org/10.7752/jpes.2017.03158

Ivashchenko, O. (2020). Research Program: Modeling of Motor Abilities Development and Teaching of Schoolchildren. Teoriâ ta Metodika Fizičnogo Vihovannâ, 20(1), 32-41. https://doi.org/10.17309/tmfv.2020.1.05

Marchenko, S., \& Dykhanova, A. (2019). Motor Abilities: Peculiarities of Effects of Volleyball Training on Coordination Preparedness of Girls Aged 15. Teoriâ ta Metodika Fìičnogo Vihovannâ, 19(1), 23-28. https://doi.org/10.17309/tmfv.2019.1.03

Marchenko, S., \& Taranenko, O. (2020). Managing the Effectiveness of Teaching Boys Aged 10 Mawashi-Geri (Roundhouse Kick) Technique in Kyokushin Karate. Teoriâ ta Metodika Fizičnogo Vihovannâ, 20(4), 262-268. https://doi.org/10.17309/tmfv.2020.4.10

Chan, C. H. S., Ha, A. S. C., \& Ng, J. Y. Y. (2018). Perceived and actual movement skill competence: The association among primary school children in Hong Kong. Journal of Motor Learning and Development, 6, S351-S365. https://doi.org/10.1123/jmld.2016-0070

Chan, C. H. S., Ha, A. S. C., Ng, J. Y. Y., \& Lubans, D. R. (2019). Associations between fundamental movement skill competence, physical activity and psycho-social determinants in Hong Kong Chinese children. Journal of Sports Sciences, 37(2), 229-236. https://doi.org/10.1080/02640414.2018.1490055

Valentini, N. C., Pierosan, L., Rudisill, M. E., \& Hastie, P. A. (2017). Mastery and exercise play interventions: Motor skill development and verbal recall of children with and without disabilities. Physical Education and Sport Pedagogy, 22(4), 349-363. https://doi.org/10.1080/17408989.2016.1241223

Nobre, F. S. S., Valentini, N. C., \& Rusidill, M. E. (2020). Applying the bioecological theory to the study of fundamental motor skills. Physical Education and Sport Pedagogy, 25(1), 29-48. https://doi.org/10.1080/17408989.2019.1688772

Almeida, G., Luz, C., Martins, R., \& Cordovil, R. (2017). Do children accurately estimate their performance of fundamental movement skills? Journal of Motor Learning and Development, 5(2), 193-206. https://doi.org/10.1123/jmld.2016-0030

Basman, A. J. (2019). Assessment criteria of fundamental movement skills for various age groups: A systematic review. Journal of Physical Education and Sport, 19(1), 722-732. https://doi.org/10.7752/jpes.2019.01104 
Barnett, L. M., Telford, R. M., Strugnell, C., Rudd, J., Olive, L. S., \& Telford, R. D. (2019). Impact of cultural background on fundamental movement skill and its correlates. Journal of Sports Sciences, 37(5), 492-499.

https://doi.org/10.1080/02640414.2018.1508399

Kapkan, O., Khudolii, O., \& Bartik, P. (2019). Motor Skills

Development: Optimization of Teaching Boys Aged 14.

Teoriâ ta Metodika Fizičnogo Vihovannâ, 19(3), 148-155. https://doi.org/10.17309/tmfv.2019.3.06

Lopatiev, A., Ivashchenko, O., Khudolii, O., Pjanylo, Y., Chernenko, S., \& Yermakova, T. (2017). Systemic approach and mathematical modeling in physical education and sports. Journal of Physical Education and Sport, 17(1), 146-155.

https://doi.org/10.7752/jpes.2017.s1023

Marchenko, S., Jagiello, W., Iermakov, S., Ivashchenko, O., \& Khudolii, O. (2021). Pattern recognition: modes of teaching boys aged 10 mae-geri (front kick) technique in kyokushin karate. Archives of Budo, 17, 253-261.

Khudolii, O.M. (2008). Osnovy metodyky vykladannia himnastyky: Navch. posibnyk. U 2-kh tomakh. 4-e vyd., vypr. i dop. Kharkiv: “OVS”, T. 1, 408.

Shlemin, A.M. (1973). Iunyi gimnast. M.: Fizkultura i sport, 376.

\title{
РОЗПІЗНАННЯ ОБРАЗІВ: ЕФЕКТИВНІСТЬ ПРОЦЕСУ НАВЧАННЯ АКРОБАТИЧНИХ ВПРАВ ДІВЧАТ 15 РОКІВ
}

\author{
Давид Медко $^{1 \mathrm{ABCD}}$, Олег Худолій ${ }^{\mathrm{ABCD}}$ \\ 1Харківський національний педагогічний університет імені Г.С. Сковороди \\ Авторський вклад: А - дизайн дослідження; В - збір даних; C - статаналіз; D - підготовка рукопису; Е - збір коштів \\ Реферат. Статья: 6 с., 9 табл., 2 рис., 22 джерела.
}

Мета дослідження - визначити вплив режимів виконання вправ на ефективність процесу навчання перевороту убік дівчат 15 років.

Матеріали і методи. У дослідженні прийняли участь 20 дівчат 15 років. Діти та іхні батьки були інформовані про всі особливості дослідження і дали згоду на участь в експерименті. Для вирішення поставлених завдань були використані методи дослідження: вивчення та аналіз науково-методичної літератури; педагогічне спостереження, хронометраж навчальних завдань; педагогічний експеримент, методи математичної статистики, дискримінантний аналіз.

Результати. Аналіз середніх значень вказує, що статистично значущі розбіжності у кількості повторень спостерігаються у виконанні 1,2 та 4 серій навчальних завдань ( $<<0,05)$. Дівчата 15 років, які використовують перший режим (6 підходів по 1 разу з інтервалом відпочинку 60 c), витрачають менше повторень на оволодіння рухів першої (вправи для розвитку рухових здібностей) та другої (вправи на оволодіння вихідних і кінцевих положень) серій завдань.
Дівчата, які використовують другий режим (6 підходів по 2 рази з інтервалом відпочинку 60 с), витрачають менше повторень на оволодіння рухів четвертої серії завдань (уміння оцінювати виконання рухів в просторі, за часом і м'язовими зусиллями) $(\mathrm{p}<0,05)$

Висновки. Дискримінантний аналіз дозволив визначити вплив кількості повторень на ефективність формування навички виконання перевороту убік дівчат 15 років.

У процесі формування рухових навичок можуть використовуватися як перший так і другий варіант режиму виконання фізичних вправ та інтервалу відпочинку. Для 1, 2 серії завдань рекомендується використовувати 6 підходів по 1 разу з інтервалом відпочинку 60 с; для 3, 5 і 6 серії завдань - 6 підходів по 1 разу з інтервалом відпочинку 60 с або 6 підходів по 2 рази з інтервалом відпочинку 60 с; для 4 серія - 6 підходів по 2 рази з інтервалом відпочинку 60 c.

Ключові слова: дискримінантний аналіз, дівчата 15 років, акробатичні вправи, режим виконання вправ, навчання.

\section{Information about the authors:}

Medko Davyd: davidmedko777@gmail.com; https://orcid.org/0000-0002-6091-2162; H. S. Skovoroda Kharkiv National Pedagogical University, Department of Theory and Methodology of Physical Education, Alchevskykh St, 29, Kharkiv, 61002, Ukraine.

Khudolii Oleg: khudolii@hnpu.edu.ua; https://orcid.org/0000-0002-5605-9939; H. S. Skovoroda Kharkiv National Pedagogical University, Department of Theory and Methodology of Physical Education, Alchevskykh St, 29, Kharkiv, 61002, Ukraine.

Cite this article as: Medko, D., \& Khudolii, O. (2021). Pattern Recognition: Effectiveness of Teaching Girls Aged 15 Acrobatic Exercises. Journal of Learning Theory and Methodology, 2(3), 134-139. https://doi.org/10.17309/jltm.2021.3.05

Received: 25.09.2021. Accepted: 05.10.2021. Published: 30.10.2021

This work is licensed under a Creative Commons Attribution 4.0 International License (http://creativecommons.org/licenses/by/4.0). 